SVU- International Journal of Veterinary Sciences, 3 (2): 51-59, 2020.

Print ISSN: 2535-1826

\title{
Survey of Toxoplasma gondii antibodies in retail red meat samples in Erbil governorate, Kurdistan Region, Iraq
}

\section{Dhary Alewy Almashhadany}

Department of Medical Lab Science (DMLS), College of Science (CSCN), Knowledge University (KNU), Iraq.

\section{Abstract}

Since livestock meat, has been demonstrated to be a potential source of human infection, a careful evaluation of the prevalence of infection with $T$. gondii in these animals' meat is needed to protect public health. Latex agglutination test (LAT) and enzyme-linked immunosorbent assay (ELISA) were performed on meat juice from 380 red meat samples (125 Beef, 135 Mutton, and 120 goats' meat) that are sold in Erbil governorate, Kurdistan region, Iraq. The current results demonstrated that the overall prevalence of anti-T. gondii antibodies among red meat was $18.7 \%$ and $16.3 \%$ according to LAT and ELISA, respectively. The highest rate was found in October (25.8\% and 22.6\%) by using LAT, and ELISA, respectively. While, the lowest rate was recorded in August (12.5\% and 9.4\%) by both assays, respectively. Both tests performed similarly without significant difference between their performances as diagnostic tests. Moreover, no significant differences between meat types were found in terms of toxoplasmosis antibodies. In conclusion the current survey provides significant evidence about risk of human exposure to $T$. gondii through the consumption of raw or undercooked red meat potentially contaminated with infectious tissue cysts.

Keywords: Toxoplasmosis, Latex, ELISA, Meat juice, Prevalence.

DOI: 10.21608/svu.2020.31892.1057 Received: June 05, $2020 \quad$ Accepted: September 6, 2020 Published: September 16, 2020.

*Corresponding Author: Dhary Alewy Almashhadany. E-mail: dhary.hammed@knu.edu.iq Citation: Almashhadany, Survey of Toxoplasma gondii antibodies in retail red meat samples in Erbil governorate, Kurdistan Region, Iraq SVU-IJVS 2020, 3 (2): 51-59.

Copyright: (C) Almashhadany. This is an open access article distributed under the terms of the creative common attribution license, which permits unrestricted use, distribution and reproduction in any medium provided the original author and source are created.

Competing interest: The authors have declared that no competing interest exists. 


\section{INTRODUCTION}

Toxoplasmosis is a worldwide significant food-borne zoonotic disease that results from the infection with an obligate intracellular protozoan parasite named Toxoplasma gondii. It is a major public health problem producing a wide range of clinical syndromes in humans, particularly pregnant women and immunosuppressed individuals, land and sea mammals, and various bird species (McLeod et al., 2020). $\mathrm{T}$. gondii has been recovered from all locations throughout the world, except Antarctica, and is described as a 'Silent threat' in most of the Asian countries (Sroka et al., 2019; Simon et al., 2020). Felidae are the only definitive hosts that excrete million oocysts of $\mathrm{T}$. gondii in their feces and thus contaminate the environment.

T. gondii has a complex life cycle that consists of two stages; sexual and asexual phases. Sexual reproduction takes place in cats where oocysts are formed and excreted with feces. Meiosis of oocysts in the environment leads to formation of sporozoites that are infectious to the intermediate hosts (rodents and livestock animals). In the intermediate hosts, rapidly replicating tachyzoites are disseminated throughout the body forming tissue cysts containing bradyzoites (Dubey, 2020). Ingestion of tissue cysts by carnivorous or omnivorous animals leads to transmission to other intermediate hosts or cats repeating the sexual phase of the life cycle. The asexual stage takes place in the intermediate hosts where rapid intracellular growth of the parasite as tachyziote takes place. The tachyziotes are spread throughout the body leading to development of tachyzoites to cysts mainly in neural and muscular tissues that can persist for long time (Dubey et al., 2012; Hosseini et al., 2020; Paneth et al., 2019).
Human acquire the infection by consumption of insufficiently cooked or raw meat containing the tissue cysts or water contaminated with oocysts or contaminated food utensils. Trans-placental infection route is another significant way of transmission which often leads to severe and lifelong disabilities in the infected infant. However, food-producing animals may represent a real risk for transmission of the disease to humans, either directly or through farming (Dubey \& Jones, 2008; Ranucci et al., 2020). Furthermore, there is no available data about the proportion of the infection among red meat animals in Erbil governorate, Iraq. Therefore, this work aimed to determine the prevalence of antiT. gondii antibodies among red meat using two serological assays; Latex agglutination test (LAT) and ELISA techniques.

\section{MATERIALS AND METHODS}

\section{Study design and sampling}

A total of 380 fresh steak red meat samples (125 Beef, 135 Mutton, and 120 Goats meat) were randomly and aseptically collected from retail shops in city center and outskirt of Erbil city during the period from July to December 2019 according to previously published method (AlMashhadany, 2019b). About 200-250g of each sample were placed in separate sterile polyethylene bags within cold container and transported to Department of Medical Lab Science (DMLS), College of Science (CSCN), Knowledge University (KNU). Meat juice was prepared according to previously published protocols (AlMashhadany, 2019a; Wallander et al., 2015). Briefly, after one week of deep freezing, samples were thawed at $20-25^{\circ} \mathrm{C}$. About $5 \mathrm{ml}$ of meat juices were collected in an Eppendorf tube and separated by centrifugation into two parts; for LAT and ELISA assays. For each different meat type, 
a number of 19 - 24 samples were tested on monthly basis.

\section{Detection of T. gondii antibodies by LAT}

Meat juice collected from beef, sheep, and goat meats were screened for antibodies to $\mathrm{T}$. gondii using Latex agglutination test (Toxocell-latex ${ }^{\circledR} \quad 3000-4525, \quad$ Biokit Company, Spain) according to the manufacturer's instructions. Briefly, this serological test is based on the principle of antigen-antibody complex formation. If specific anti-Toxoplasma antibodies exist in examined sera, they will react with soluble Toxoplasma antigen in the latex reagent and will be visualized by latex particles as whitish granules after 5 minutes of turning of the slide.

\section{Detection of $T$. gondii antibodies by ELISA}

The extracted meat juice samples were also assayed for the presence of IgG antibodies to $\mathrm{T}$. gondii by ELISA test using antigen and other regencies from commercial kit (BioCheck BC-1085 kit, California, USA) according to manufacturer's instructions. Negative and positive controls were run in parallel by kits provided by the same manufacturer. The optical density (OD) values were read at $450 \mathrm{~nm}$ using a microplate spectrophotometer Thermo Scientific TM Multiskan TM GO (Fisher Scientific, Delaware, USA).

\section{Statistical analysis}

Data were analyzed using the SPSS software version 25 . Confidence intervals of prevalence were estimated using Clopper-Pearson method at 0.95 confidence level. Chi square test was employed to test the difference between groups. To evaluate the agreement between the two tests, interrater reliability (kappa) was calculated and kappa values $(\kappa)$ were considered as follows: poor agreement $(\mathrm{K}<0.20)$; fair agreement $\quad(\kappa=0.21-0.40) ; \quad$ moderate agreement $(\mathrm{K}=0.41-0.60)$; good agreement $(\mathrm{K}=0.610 .80)$; and very good agreement $(\mathrm{K}$ $=0.81-1.00)$.

\section{RESULTS}

\section{Surveillance of T. gondii antibodies}

The obtained results showed that anti$\mathrm{T}$. gondii antibodies were found in 71 out of the 380 meat samples $(18.7 \%)$ with the LAT test, whereas $62(16.3 \%)$ samples of meat juices were found to be seropositive for toxoplasmosis by ELISA. There was no significant different between the two assays for detection of $\mathrm{T}$. gondii antibodies in meat juice samples $(p=0.373)$. The distribution of positive samples among different meat types for anti-T. gondii antibodies showed that the higher prevalence was recorded among mutton meat $(21.5 \%$ and $19.3 \%)$ as compared to goat (19.2\% and $15.8 \%)$ and beef meat (13.6\% and $15.8 \%)$ as depicted in Table (1). However, there was no significant difference between meat types in terms of harboring anti-T. gondii antibodies $(p=0.411)$. Agreement between the two tests using Kappa analysis revealed a very good agreement $(\mathrm{K}=0.918$, with $95 \%$ CI of 0.865 to $0.97 \%$ ).

Table 1. Prevalence of $T$. gondii antibodies among red meat samples $(n=380)$.

\begin{tabular}{|c|c|c|c|c|c|}
\hline \multirow{2}{*}{$\begin{array}{l}\text { Meat } \\
\text { type }\end{array}$} & \multirow{2}{*}{$\begin{array}{c}\text { No. } \\
\text { examined }\end{array}$} & \multicolumn{2}{|c|}{ LAT positive } & \multicolumn{2}{|c|}{$\begin{array}{l}\text { ELISA } \\
\text { positive }\end{array}$} \\
\hline & & n (\%) & $\begin{array}{c}95 \% \\
\text { CI }\end{array}$ & $\mathrm{n}(\%)$ & $\begin{array}{c}95 \% \\
\text { CI }\end{array}$ \\
\hline Beef & 125 & $\begin{array}{c}19 \\
(15.2)\end{array}$ & $\begin{array}{l}9.41- \\
22.71\end{array}$ & $\begin{array}{c}17 \\
(13.6)\end{array}$ & $\begin{array}{l}8.13- \\
20.88\end{array}$ \\
\hline Mutton & 135 & $\begin{array}{c}29 \\
(21.5)\end{array}$ & $\begin{array}{l}14.88- \\
29.37\end{array}$ & $\begin{array}{c}26 \\
(19.3)\end{array}$ & $\begin{array}{l}12.98- \\
26.93\end{array}$ \\
\hline $\begin{array}{l}\text { Goats } \\
\text { meat }\end{array}$ & 120 & $\begin{array}{c}23 \\
(19.2)\end{array}$ & $\begin{array}{l}12.56- \\
27.36\end{array}$ & $\begin{array}{c}19 \\
(15.8)\end{array}$ & $\begin{array}{l}\text { 9.81- } \\
23.62\end{array}$ \\
\hline Total & 380 & $\begin{array}{c}71 \\
(18.7)\end{array}$ & $\begin{array}{l}14.89- \\
22.97\end{array}$ & $\begin{array}{c}62 \\
(16.3)\end{array}$ & $\begin{array}{l}12.74- \\
20.42\end{array}$ \\
\hline
\end{tabular}

* No significant difference was found between meat types in terms of $\mathrm{T}$. gondii prevalence $(\mathrm{p}=0.411)$. 
Prevalence of $T$. gondii antibodies according to sampling location

The present survey illustrated that the highest prevalence was found in suburban area $(18.3 \%-24.3 \%)$ as compared to urban area $(12.3 \%-17.1 \%)$. A statistically significant difference was found between anti-T. gondii prevalence and screened regions by ELISA $(\mathrm{p}=0.03)$ and LAT tests $(\mathrm{p}=0.05)$ respectively, as shown in Table (2).

Table 2. Prevalence of $T$. gondii antibodies (ELISA) according to sampling location.

\begin{tabular}{|lcccc|}
\hline & \multicolumn{2}{c}{ Urban } & \multicolumn{2}{c|}{ Suburban } \\
\cline { 2 - 5 } Meat & No. & No. of & No. & No. of \\
type & tested & positive (\%) & tested & positive \\
& & & & $(\%)$ \\
\hline Beef & 65 & $6(9.2)$ & 60 & $11(18.3)$ \\
\hline Mutton & 70 & $11(15.7)$ & 65 & $14(21.5)$ \\
\hline Goats & 60 & $7(11.7)$ & 60 & $13(21.7)$ \\
meat & & & & \\
\hline Total & 195 & $24(12.3)$ & 185 & $38(20.5)$ \\
\hline
\end{tabular}

Temporal variations of $T$. gondii prevalence during study period

In regard to monthly dynamics, the current results showed that the highest rate of anti -T. gondii antibodies was detected in October $(25.8 \%)$ and September $(20.0 \%)$, while the lowest rate was found in August (12.5\%) according to LAT. However, the highest rate of anti-T. gondii antibodies according to ELISA results was detected in October $(22.6 \%)$ and December (19.4\%), with the lowest rate in August (9.4\%). According to the two assays, there was only a weak association $(\mathrm{r} 2=0.254 \& 0.348$ for LAT \& ELISA, respectively) between progress of summer-autumn months and increase in prevalence of anti-T. gondii antibodies (Table $3 \&$ Figure 1).

Table 3. Prevalence of $T$. gondii antibodies in different red meat at time scale.

\begin{tabular}{|cccc|}
\hline Month & $\begin{array}{c}\text { Total } \\
\text { examined } *\end{array}$ & $\begin{array}{c}\text { LAT } \\
\text { positive } \\
\mathbf{n}(\boldsymbol{\%})\end{array}$ & $\begin{array}{c}\text { ELISA } \\
\text { positive } \\
\mathbf{n}(\boldsymbol{\%})\end{array}$ \\
\hline July & 63 & $10(15.9)$ & $9(14.3)$ \\
\hline August & 64 & $8(12.5)$ & $6(9.4)$ \\
\hline September & 65 & $13(20.0)$ & $11(16.9)$ \\
\hline October & 62 & $16(25.8)$ & $14(22.6)$ \\
\hline November & 64 & $12(18.8)$ & $10(15.6)$ \\
\hline December & 62 & $12(19.4)$ & $12(19.4)$ \\
\hline Total & $\mathbf{3 8 0}$ & $\mathbf{7 1 ( 1 8 . 7 )}$ & $\mathbf{6 2}(\mathbf{1 6 . 3 )}$ \\
\hline \hline
\end{tabular}

*Monthly examined samples comprised approximately equal proportions of beef, mutton, and goat meat.

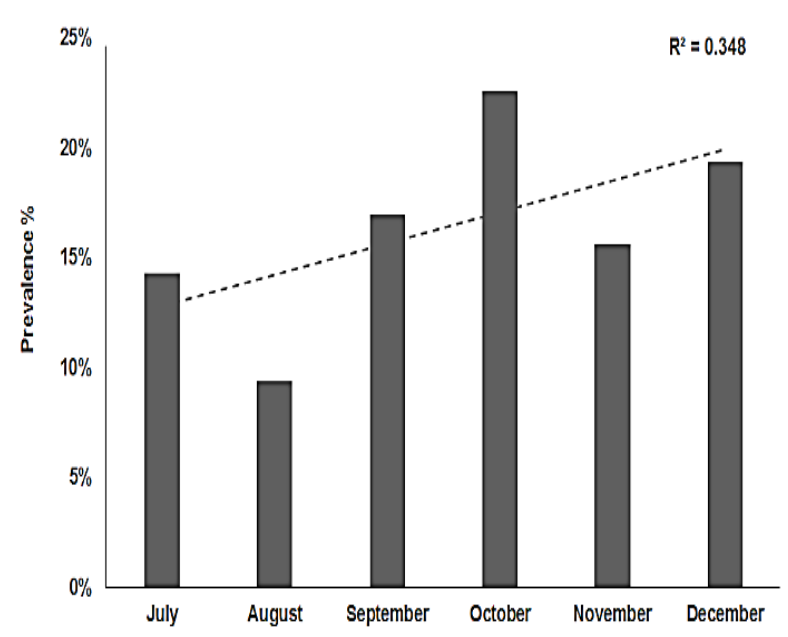

Figure 1. Temporal variations of $T$. gondii prevalence during study according to ELISA assay. 


\section{DISCUSSION}

Seroprevalence is a good indicator of the presence and tracking of $T$. gondii in meat introduced into market especially when nation-wide surveillance programs are scarce. This results of total prevalence are consistent with data published by Tonouhewa and colleagues who reported that the prevalence of anti-T. gondii antibody among cattle, sheep, goats from different African countries was $12.0 \%$, $26.1 \%$, and 22.9\%, respectively (Tonouhewa et al., 2017).

On the other hand, an Algerian study documented the presence of antiToxoplasma antibodies in cattle, sheep, and goats were $3.92 \%, 11.59 \%$, and $13.21 \%$ (Dechicha et al., 2015). However, our results are lower than prevalence found in Mosul governorate (Iraq) (27\%) (Zakaria, 2011), but higher than recently documented in Al-Diwaniyah province (Iraq) $(17.5 \%)$ (Sakban \& A'aiz, 2020). In contrast, significantly higher prevalence findings were reported from Ethiopia (24\%) (Tilahun et al., 2018), Czech Republic (28\%) (Lorencová et al., 2016), Tunisia (28.37\%) (Amdouni et al., 2017), Yemen (28.94\%) (Al-Shaibani et al., 2018), Poland (37.7\%) (Kornacka et al., 2020), Lebanon (38\%) (El Safadi et al., 2019), and Pakistan (42.80\%) (Ullah et al., 2018).

Such variations are mostly attributed to difference in geographical locations, rearing practice, farm hygiene, and different diagnostic tests (serological, molecular, and bioassays) (Peyron et al., 2019). Indeed, the common method of rearing sheep and goats increases the likelihood of contact with environments polluted by oocysts, such as pastures, water, soil, and thereby increases the hazard of infection among farm animals (The European Food Safety Authority, 2013; Guo et al., 2015).
Urban areas tend to have lower prevalence due to less contact with wildlife and availability of veterinary care. It was reported that animals from farms visited by a veterinarian were less infected than farms without any veterinary care (Dahourou et al., 2019). In the study conducted by Sroka and associates, the highest prevalence of $\mathrm{T}$. gondii DNA was among raw meat products obtained for samples originating from south-east regions of Poland-Podkarpackie (17.9\%) and Małopolskie (12.6\%) (Sroka et al., 2019). These are mountainous regions with numerous small farms, where pigs are often free-range reared and might have direct contact with cats, wild animals, and other potential sources of $\mathrm{T}$. gondii infection.

Results of temporal variations (Table 3 ) are in good agreement with a very recent study in Al-Diwaniyah province, Iraq, a study confirmed that the autumn season (September, October, and November) was associated with increased prevalence and recorded significantly higher rates of infection in beef (Sakban \& A'aiz, 2020). Moreover, another study confirmed that the overall $T$. gondii prevalence in retail fresh meat was higher in spring collection months, particularly during April and May, than in the summer or fall (Iqbal et al., 2018). Furthermore, the seroconversion rates varied from 0.42 to 0.96 seroconversions per year and were higher in autumn and winter than in spring and summer (Simon et al., 2018).

In Erbil, temperature decreases gradually during the second half of the year. This may provide chances for the oocysts to sustain viability and increase in infections. Indeed, it has been suggested that toxoplasmosis decreases during warmer, drier seasons because of the decreased number of viable oocysts in the environment (Logar et al., 2005). 
Additionally, similar observations were reported from Iran where intermediate hosts were found to be more infected in the summer season $(34.48 \%)$, while prevalence in other seasons (winter, spring, and autumn) was $30.44 \%, 18.18 \%$, and $19.05 \%$, respectively (Mosallanejad et al., 2012).

\section{CONCLUSION}

The results of this study provide baseline information on the occurrence of toxoplasmosis in red meat in the regions of Iraq and refer to an important human health and hygienic risk associated with the consumption of raw and undercooked meat from these animal species. It is vital to raise awareness of people regarding $T$. gondii infection. Consequently, national preventive strategies should be applied to avoid and control $\mathrm{T}$. gondii transmission between food-producing animals and humans.

\section{CONFLICT OF INTEREST}

The author declares that there is no conflict of interest.

\section{REFERENCES}

Al-Mashhadany DA (2019a). Application of Rose Bengal Test and ELISA in Meat Juice for Monitoring of Brucellosis among Cattle Carcasses at Erbil City, Iraq. Bulletin of University of Agricultural Sciences and Veterinary Medicine ClujNapoca. Animal Science and Biotechnologies. 76 (1), 14-20.
Al-Mashhadany DA (2019b). Occurrence and antibiogram of listeria monocytogenes isolates from retail meat shops at Erbil city, Kurdistan region, Iraq. Italian Journal of Food Safety. 8 (4), 194-198.

Al- Shaibani IRM, Al_Mahdi H, Alshwkani A (2018). Epidemiological Study on Toxoplasmosis of Human and Animals at Dhamar Governorate, Yemen. International Journal of Current Microbiology and Applied Sciences. 7 (12), 12.

Almashhadany DA (2020). Application of ELISA for Monitoring Toxoplasma gondii among Retail Sheep Meat in Erbil Governorate, Kurdistan Region, Iraq. Malaysian Journal of Microbiology. (In press).

Amdouni Y, Rjeibi MR, Rouatbi M, Amairia S, Awadi S, Gharbi M (2017). Molecular detection of Toxoplasma gondii infection in slaughtered rumipora caninum infections in household's sheep "Elevage en case" in Dakar, Senegal. Veterinary World. 12 (7), 1028-1032.

Dechicha A.S, Bachi, F, Gharbi, I, Gourbdji, E, Baazize-Ammi, D, Guetarni, D. (2015). Sero-epidemiological survey on toxoplasmosis in cattle, sheep and goats in Algeria. African Journal of Agricultural Research. 10 (20), 2113-2119.

Dubey J., 2020. The history and life cycle of Toxoplasma gondii. In: Toxoplasma gondii: The Model Apicomplexan Perspectives and Methods 3rd edn., Weiss L.M. and K. Kim, (Eds.). Academic Press. pp. 1-19.

Dubey JP, Jones JL (2008). Toxoplasma gondii infection in humans and animals in the United States. 
International

Journal

Parasitology. 38 (11), 1257-1278.

Dubey JP, Lago EG, Gennari SM, Su C, Jones JL (2012). Toxoplasmosis in humans and animals in Brazil: high prevalence, high burden of disease, and epidemiology. Parasitology. 139 (11), 1375-1424.

Guo M, Dubey JP, Hill D, Buchanan RL, Gamble HR, Jones JL, Pradhan AK (2015). Prevalence and risk factors for Toxoplasma gondii infection in meat animals and meat products destined for human consumption. Journal of food protection. 78 (2), 457-476.

Hosseini SA, Golchin E, Sharif M, Sarvi S, Ahmadpour E, Rostamian A, Gholami S, Amouei A, Daryani A (2020). A serological investigation and genotyping of Toxoplasma gondii among Iranian blood donors indicates threat to health of blood recipients. Transfusion and Apheresis Science. (ahead of print), 102723.

Iqbal A, Janecko N, Pollari F, Dixon B (2018). Prevalence and molecular characterization of Toxoplasma gondii DNA in retail fresh meats in Canada. Food and Waterborne Parasitology. 13e00031.

Kornacka A, Moskwa B, Werner A, Nowosad P, Jankowska W, Cybulska A, Majewska AC (2020). The Seroprevalence of Toxoplasma gondii in Wild Boars from Three Voivodeships in Poland, MAT Analyses. Acta Parasitologica. (ahead of print), 1-6.
Logar J, Šoba B, Premru-Sršen T, NovakAntolič Ž (2005). Seasonal variations in acute toxoplasmosis in pregnant women in Slovenia. Clinical Microbiology and Infection. 11 (10), 852-855.

Lorencová A, Lamka J, Reslová N, Škorpíková L, Slaný M (2016). The meat of goat kids and lambs as a possible source of Toxoplasma gondii for consumers. Maso International. 6 (1), 1805-5281.

McLeod, R., Cohen, W., Dovgin, S., Finkelstein, L., Boyer, K., 2020. Human Toxoplasma infection. In: Toxoplasma gondii: The Model Apicomplexan - Perspectives and Methods 3rd edn., Weiss L.M. and K. Kim, (Eds.). Academic Press. pp. 117-227.

Mosallanejad B, Avizeh R, Razi JMH, Hamidinejat H (2012). Seroprevalence of Toxoplasma gondii among wild rats (Rattus rattus). in Ahvaz District, Southwestern Iran. Jundishapur Journal of Microbiology. 5 (1), 332335.

Paneth A, Węglińska L, Bekier A, Stefaniszyn E, Wujec M, Trotsko N, Dzitko K (2019). Systematic Identification of Thiosemicarbazides for Inhibition of Toxoplasma gondii Growth In Vitro. Molecules. 24 (3), 614.

Peyron F, L'ollivier C, Mandelbrot L, Wallon M, Piarroux R, Kieffer F, Hadjadj E, Paris L, Garcia -Meric P (2019). Maternal and Congenital Toxoplasmosis: Diagnosis and Treatment Recommendations of a 
French Multidisciplinary Working Group. Pathogens. 8 (1), 24.

Ranucci D, Battisti E, Veronesi F, Diaferia M, Morganti G, Branciari R, Ferroglio E, Valiani A, Chiesa F (2020). Absence of Viable Toxoplasma gondii in Artisanal Raw-Milk Ewe Cheese Derived from Naturally Infected Animals. Microorganisms. 8 (1), 143.

El Safadi D, Abi Chahine D, Al Tarraf A, Raii $\mathrm{O}$, Mesto $\mathrm{K}$, Ismail MB, Hamze M (2019). First report on seroprevalence and risk factors of Toxoplasma gondii infection in sheep and goats in North Lebanon. The Journal of Infection in Developing Countries. 13 (09), 831-836.

Sakban FM, A'aiz NN (2020). Investigate the Toxoplasma gondii infection in the consumed beef in Al-Diwaniyah province. Iraqi Journal of Veterinary Sciences. 34 (1), 95-99.

Simon J, Fillaux J, Guigon A, Lavergne R-A, Villard O, Villena I, Marty PC (2020). Serological diagnosis of Toxoplasma gondii: analysis of false-positive $\mathrm{IgG}$ results and implications. Parasite. 27 (7), 1-9.

Simon J, Pradel R, Aubert D, Geers R, Villena I, Poulle ML (2018). A multi-event capture-recapture analysis of Toxoplasma gondii seroconversion dynamics in farm cats. Parasites and Vectors. 11 (1), $1-13$.

Sroka J, Bilska-Zajac E, Wójcik-Fatla A, Zajac V, Dutkiewicz J, Karamon J, Piotrowska W, Cencek T (2019). Detection and Molecular
Characteristics of Toxoplasma gondii DNA in Retail Raw Meat Products in Poland. Foodborne Pathogens and Disease. 16 (3), 195204.

The European Food Safety Authority (2013). Scientific Opinion on the public health hazards to be covered by inspection of meat from sheep and goats. EFSA Journal. 11 (6), 3265.

Tilahun B, Tolossa YH, Tilahun G, Ashenafi H, Shimelis S (2018). Seroprevalence and Risk Factors of Toxoplasma gondii Infection among Domestic Ruminants in East Hararghe Zone of Oromia Region, Ethiopia. Veterinary Medicine International. 20181-7.

Tonouhewa ABN, Akpo Y, Sessou P, Adoligbe $\mathrm{C}$, Yessinou E, Hounmanou YG, Assogba MN, Youssao I, Farougou S (2017). Toxoplasma gondii infection in meat animals from Africa: Systematic review and metaanalysis of sero-epidemiological studies. Veterinary World. 10 (2), 194-208.

Ullah MZ, Awais MM, Akhtar M, Anwar MI, Navid MT, Khan I, Razzaq A (2018). Seroprevalence, associated risk factors and hematological impacts of toxoplasmosis in small ruminants of Multan, PunjabPakistan. Tropical Biomedicine. 35 (4), 1028-1040.

Wallander C, Frössling J, Vågsholm I, Uggla A, Lunden A (2015). Toxoplasma gondii seroprevalence in wild boars (Sus scrofa). in Sweden and 
Almashhadany, 2020

evaluation of ELISA test

performance. Epidemiology \&

Infection. 143 (9), 1913-1921.

Zakaria EG (2011). Detection of Toxoplasma gondii antibodies in different meat juices. Rafidain Journal of Science. 22 (4E), 17-25. 